WALDEMAR SŁUGOCKI

\title{
Institutionalization of the development management system in Poland
}

Waldemar Sługocki, Associate Professor University of Zielona Góra Faculty of Economics and Management

\section{Introduction}

Along with the process of systemic transformation and integration of Poland with the European Union, a more and more important role has been played by development policy which is a consequence of the departure from the command-and-distribution economy to the market economy as well as the process of state decentralization. In the first phase, as early as on 8 March 1990, some competences in the public sphere were created and transferred to local government units at the basic level, and with the passage of time, with gaining new experiences, with progressing European integration process, including in particular the possibility of implementing pre-accession programs, a further reform was undertaken in territorial division of the country, by creating two further levels of local government on the basis of the acts of 5 June 1998, namely poviat and voivodship self-governments. A reform of the central administration was also carried out in this respect by establishing a department responsible for regional development matters. The progressing process of European integration and, consequently, Poland's accession to the European Union 
on 1 May 2004, the opportunity to take advantage of financial resources as part of cohesion policy was a fundamental premise to create foundations for residual and uncoordinated, but specific kind of management system, if not fully development yet, then with some of its elements. The changes initiated at that time gave impetus to further work on creating a development management model in Poland in the theoretical, legal, political and financial dimensions as well as its implementation (Sługocki 2013, pp. 111-124).

The basic objective of the article is to describe the process of formulating the development management system, paying special attention to its legal, program, institutional and financial aspects. The debate starts with the theoretical part introducing and explaining the basic concepts necessary to conduct further analysis of the discussed issues and obtaining the answer, in the author's opinion, to the fundamental question: whether the process of Poland's integration with the European Union, and especially the possibility of implementing European cohesion policy have contributed to shaping development policy, including efforts to build a development management system?

In order to acquire the answer to such a question, a retrospective presentation of the Polish acquis in the formulation of the legal, institutional, program and financial framework of the development management system is necessary, however determination of the importance of the development management system for the state is crucial.

\section{Theoretical aspects of the development policy management system}

The key to building the concept of development policy is the meaning we assign to the words 'politics', 'development', 'development policy' or 'management'. This meaning is inscribed in both the method of performing public tasks adopted in Poland, as well as the concept of economic policy and the concept of pursuing development policies adopted by the European Union. These elements shape both the essence and the character of the term "development policy". The term "politics" in the public sphere should be understood as a holistic approach to the issue of satisfying essential social needs, the result of which, on the part of the executive power, is to present a specific commitment on which executive decisions implemented by the administration will be based. Adding the word "public" to the word "politics" means that we focus on fulfilling needs, including improving the quality of life of a specific community. In a broader sense, the term "politics" should be understood as intentional actions of a government which deliberately change or affect society or the economy. However, one should 
be aware that shaping public policy is a complex and multifaceted process, within which stakeholders try to influence politicians who shape public policy in a given area (Hausner 2008, pp. 369-373). Paulina Legutko Kobus (2015) notes that the term public politics is a term that is increasingly used both in scientific communities and among politicians, one of the definitions of the term, which she cites, was formulated by J. Górinak and S. Mazur (2012), according to which public politics is the fulfillment of the agreed arrangements. The fore-mentioned fulfillment takes the form of legal acts, strategies, programs as well as specific projects. Public policy is also a response to problems appearing in public space, as well as actions taken by states to solve emerging problems. Public policy in practical terms denotes actions that have an impact on citizens, but it is also the answer to questions: whether or not, to what extent and how the government implements its programs? (Strzelecki 2015, p. 67).

However, "development" in the context of public policies, as J. Hausner points it out, should be understood as irreversible and permanent change. The development policy combines both the element of adaptation and creativity, thus depends on social experimentation and social innovation (Hausner 2008, pp. 369-373). However, in the Act of 6 December 2006 on the principles of conducting development policy, it was defined as a set of interrelated actions taken and implemented in order to secure sustainable and harmonious development of the country, socio-economic regional and spatial cohesion, raising the competitiveness of the economy and creating new jobs in national, regional or local scale (Journal of Laws No. 227/2006 item 1658, p. 1). Moreover, J. Kundera and W. Szmyt (2008, p. 79) in the "Lexicon of regional policy of the European Union", add that the development policy covers areas such as: environmental protection; healthcare; promotion of employment; development of culture, physical culture, sport and tourism; development of cities and metropolitan areas; rural development; development of science and increasing the innovativeness of the economy; development of pro-social behaviors of local communities as well as building and strengthening the structures of civil society; development of human resources, including raising the level of education of the society, qualifications of citizens, preventing social exclusion and mitigating its negative effects; stimulating the creation of new jobs; creation and modernization of social and technical infrastructure; supporting and modernizing state institutions; supporting the development of entrepreneurship; supporting economic growth; increasing the competitiveness of the economy. Public policies included in the development policy must obviously complement each other so that development policy becomes a synthesis of all detailed policies. Collective complementation 
of policies refers to two basic approaches to development policy, namely sectoral and territorial approaches. The sectoral approach is characterized by an emphasis on selected areas, in addition, it is burdened with territorial dimension deficit and integrated consideration of development processes. It leads to performing unidirectional operations which are not adjusted to local conditions. This approach introduces fragmentation of implementation systems, leading to multiplication of implementation efforts. From the point of view of territorial remediation, its disadvantage is the exclusion of regional and local entities from the implementation processes. This decreases efficiency, while resources are limited as they should not be allocated repeatedly in order to serve the same purpose. Whereas, the territorial approach postulates multidimensional development processes. It enables taking into account their social, economic and environmental conditions as well as the diversity of areas in which these processes take place.

It requires undertaking integrated actions taking into account cross-sectoral links, and thus enables public intervention in an equivalent manner and maximizing the synergy of implementation instruments. Summing up this part of the considerations, it should be stated that the territorial approach is related to addressing public intervention in order to enhance the competitiveness of regions and unblocking growth processes through a more complete application of competitiveness advantages and development potentials. Directing public policies in the territorial dimension is being developed in the European Union. An example of this approach is conforming to the Territorial Agenda of the European Union (National Strategy of Regional Development 2010-2020, 2010, pp. 15-16).

Another of the terms that needs to be explained in the context of further consideration of development management in Poland is the term "management". In the opinion of J. Płoskonek, J. Szlachta and J. Zaleski, it should be understood as co-ordination of actions that are performed by specific entities and are intended to achieve a specific goal in the form of some expected public asset. Often, in order to emphasize the specificity of the area, the concept of public management is introduced and understood as organization of the process of implementing public strategies satisfying essential social needs. Management seen as a process is based on the adopted strategies and serves their full implementation, while the acquired long-lasting public value is the most important result achieved. The management process distinguishes such functions as: planning, organizing, making decisions, commissioning tasks, coordinating, controlling or monitoring. Within each of these functions, 
certain instruments may be used to implement them. Public management, which is emphasized by the authorities mentioned above, is implemented by a group of public managers, namely people managing the public sphere. They are public managers acting on behalf of executive bodies and holding managerial positions in organizational units of the public finance sector. Their basic management instrument in the legal-administrative sense is the power to supervise the tasks performed or the decision-making power to reform a specific part of public administration (Górniak, Mazur 2012, pp. 71-76).

\section{Formation of the development management system in Poland}

After more than a decade of experience in formulating the development management system in Poland, mainly due to our presence in the European Union and transfer of funds from the EU budget, the time has come to analyze the acquired experience, the reflection and an attempt to reformulate the development management system.

It should be remembered that after 1990, the development management policy was provisional and bottom-up in its character, the management system was not there yet. At the national level, both the legislative framework and relevant strategic documents were missing, despite the fact that many Polish communes had strategic documents to plan investments in an orderly and thoughtful way. As M. K. Zwierżdżyński emphasizes in the article "Strategies for the development of Poland: system analysis, challenges and recommendations", the situation was opposite to the model one, because first operational documents were created, and only later strategies. The most important strategic goal of Poland at that time was the development of civilization, even at the high cost of increasing the interregional disparities. In the following years, de facto, at the turn of the 20th and 21st centuries, the role of the country's compass was played by the efforts to integrate with the European Union. Poland's accession to OECD in 1996 followed by joining NATO in 1999 and the European Union in 2004 closed the period of Poland's basic strategic goals initiated by the 1989 transformation process. A number of objectives pursued at that time were rather short-term and extemporary (Zwierżdżyński 2015, pp. 14-15), and they were initially implemented mainly thanks to support of the Phare program, and since 2000 thanks to pre-accession funds which created the new Phare, ISPA and SAPARD perspectives (Sługocki 2005, pp. 42-60).

However, establishing and operation of the Task Force for Regional Development in Poland was, both, in the intellectual and practical dimensions, 
a very crucial event. Their efforts were later on continued by the Task Force for Structural Policy in Poland. This context was also reflected in the work carried out by the Representative for Constitutional Reform of State in the form of legal regulations concerning self-government at the level of voivodship and the office of the voivode. It should be noted that the reform of public administration and territorial organization of the country, which came into force on January 1, 1999, was of fundamental importance for shaping the foundations of development policy (Jakubowski, Sługocki, 2014, pp. 21-29). The introduction of these changes in its assumptions was to contribute to (Gilowska et al. 2001, p. 11):

- increasing state control through decentralization and de-concentration of competences,

- organizing the territorial system by creating new categories of local government units (self-government voivodships and poviats),

- changes in the public finance system by increasing the share of local government units in public finances,

- building democratic institutions of civil society by introducing representation of regional and local communities at all levels, elected in direct elections,

- adaptation of territorial organization of the country and self-government structures to solutions already approved of in the European Union.

The successive process of Poland's accession to the European Union was conducive to undertaking many positive and desirable directions of changes. They took place in many fields, positively affecting the efficiency of public tasks carried out primarily thanks to transfers of funds from the European Union budgets, although one should remember that in accordance with the additionality principle, these transfers were partially co-financed by public and private funds of entities operating within the recipient state borders.

An important regulation creating further foundations for the implementation of development policy was the Act of 12 May 2000 on the principles of regional development support, identifying regional policy purposes, which, on the one hand accounts for supporting the development of individual regions, improving their competitiveness and the standard of living of their inhabitants, and on the other hand, contributing to strengthening the economic cohesion and territorial integrity of the state. Conducting such a policy should be based on the principle of sustainable development. Support for regional development was defined in the Act as "territorially oriented set of activities of the Council of Ministers and government administration for sustainable socio-economic development and environmental protection conducted in cooperation with local government units as well as social and economic partners". Supporting 
regional development should be carried out on the basis of the National Regional Development Strategy and voivodship self-government initiatives in accordance with the principle of sustainable development. The purposes of supporting regional development, among others were: development of individual areas of the country, improvement of living quality and conditions for the inhabitants, and increasing the level of satisfying the needs of self-government communities; creating conditions for increasing the competitiveness of self-government communities, diminishing differences in the level of development of individual areas of the country and equalizing opportunities for the citizens of the state, regardless of the place of residence, as well as reducing the backwardness of less-developed areas characterized by least favorable development conditions. The act stipulates that the strategy should be created taking into account the development strategy of voivodships and international commitments of Poland. The state's regional policy is to be implemented through coordinated financial support for projects included in voivodship programs. It was up to a voivodship self-government to perform regional policy tasks of the state and tasks of the European regional development policy confined to the particular voivodship territory.

It is especially about the convergence of voivodship development strategies and provincial programs (on the basis of which the local government will apply for financial support) with the state regional policy program (Churski 2008, pp. 47-48).

Recognition of the importance of regional policy in addition to the establishment of self-governing voivodships was also reflected in 1999 when, according to the law on government administration departments, the minister competent for regional development was appointed. In the years 2000-2001, the Minister of Regional Development and Civil Engineering was the member of the Council of Ministers, and in the years 2001-2005 the issue of regional development was the responsibility of the Minister of Economy. In 2005, the Minister for Regional Development was re-appointed, coordinating regional policy and activities in the field of European cohesion policy in Poland. The creation of a separate ministry emphasized the growing importance of the issues of regional development. The responsibilities of the Minister for Regional Development include, among others, coordinating cooperation with individual segments of government and self-government administration, and agreeing on the form and scope of support provided to the voivodship self-governments. An important competence of the minister for regional development in 2001-2006 was the preparation of two basic strategic documents, namely the National Strategy 
for Regional Development 2001-2006 and the National Development Plan (MRR Report 2007, pp. 44-45). In addition, at that time, a number of documents were developed for the purposes of creating and implementing regional policy: the concept of medium-term economic development up to 2002; public finance and economic development strategy, The Concept of the National Spatial Planning, long-term strategy of sustainable and balanced development; national sectoral strategies (employment, rural development and agriculture, environmental protection, transport development, fisheries). Strategic directions of regional development were established in the adopted in 2000 the aforementioned National Strategy for Regional Development for the years 2001-2006, which was the basis for activities at the national and provincial level. NSRD was also crucial for regional policy in Poland in the pre-accession period, as it set out objectives, priorities, criteria for identifying support areas, support rules, principles and measures to support voivodship programs, and ways to link them to the state budget and pre-accession funds. It should be noted that this document was substantively consistent with the National Development Plan, which, apart from the regional approach, also contained a sectoral approach (Adamowicz 2011, p. 67). The achievements in building the foundations for development policy in the years 1990-2004 are presented in the figure below. One should be aware of the rudiments, deficiencies and lack of political will to create a full development policy model, however, it is difficult to agree with the thesis, which also appeared in scientific studies, that most of the strategies looked like a "radio request show", and the strategic management itself was limited only to budgeting, management of structural funds and the Cohesion Fund. It is also difficult to fully share the view that there was no national document that would go beyond the consumption of EU funds. Still, one should agree with the statement that the goals that were then implemented were important because they gave the society comfort and tangible benefits. I hope that the facts and experiences of the Polish scientific community as well as the central and regional administration cited in the further part of the article prove that over the years we have been dealing with, perhaps too slow and imperfect, but the process of gradual creation of the Polish development management system.

The key moment for the development of regional policy was Poland's accession to the European Union on May 1, 2004. Jacek Szlachta and Janusz Zalewski (2010) in the article Directions of regional policy in Poland until 2020, stress that thanks to that milestone fact, resources and solutions of the European cohesion policy became available for our country. Poland has adopted solutions for European cohesion policy in the areas of programming, management, financing, monitoring, 
evaluation and project selection. The key choice concerned the level of decentralization of fund management.

Poland has adopted a relatively decentralized model allocating a significant range of resources and responsibilities in the field of management at the voivodship level (Szlachta, Zalewski 2010, pp. 37-38).

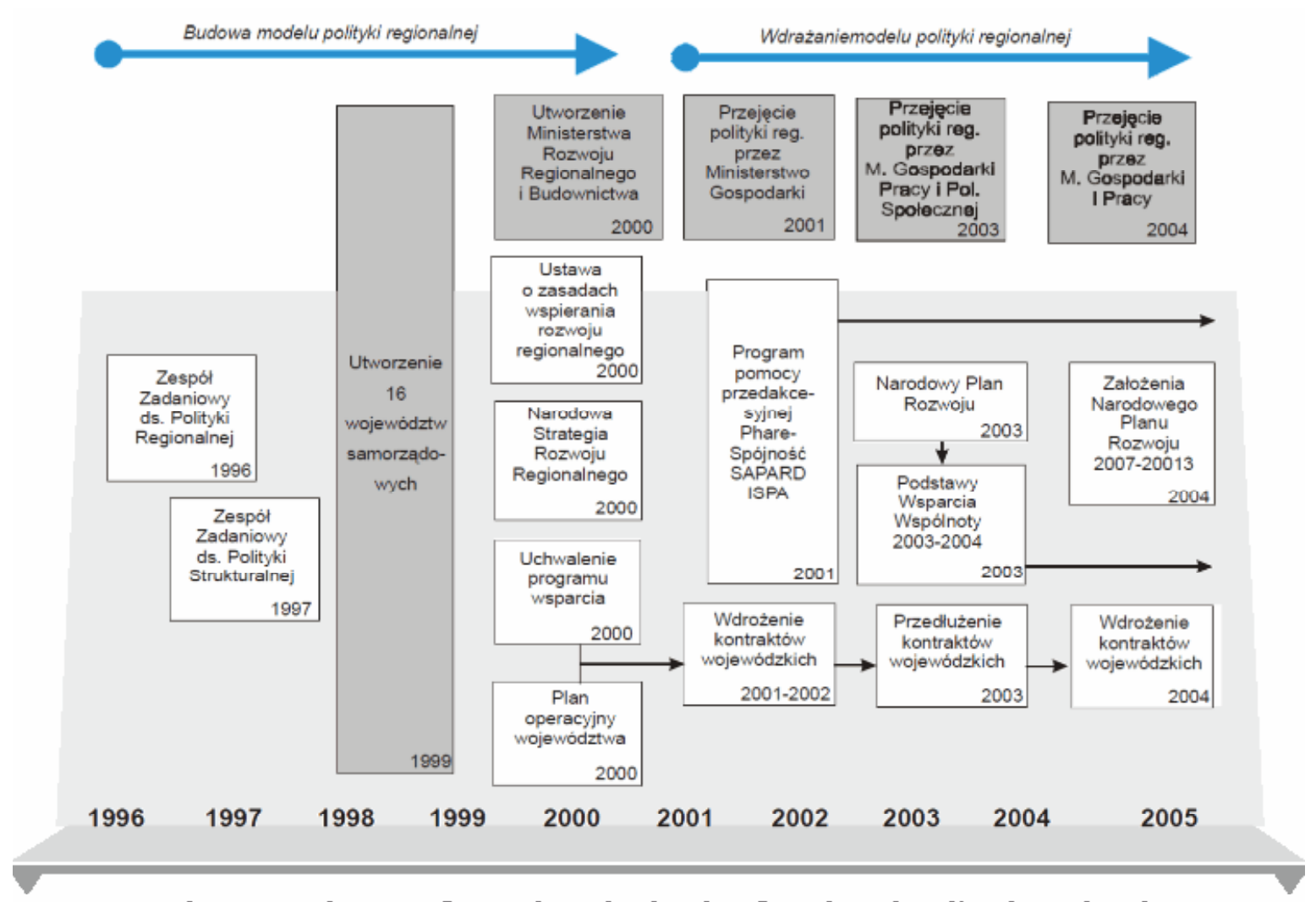

Figure 1. Phases of creating the basis of regional policy in Poland

Source: Report on regional policy, Ministry of Economy and Labor, Warsaw 2004, p. 25

Poland, following the long-term financial perspective of 2000-2006, adopted a number of legal solutions, including in particular the National Development Plan Act on April 20, 2004, which was the foundation for the implementation of operational programs implemented at that time. The National Development Plan, and earlier the Preliminary National Development Plan, was a comprehensive document defining the socio-economic strategy of Poland in the first years of membership in the European Union. It also presented the 
socio-economic map of Poland and its regions at the beginning of the country's accession to the EU, formulated objectives and a description of the strategy aimed at achieving social, economic and spatial cohesion with the countries and regions of the Community. The National Development Plan 2004-2006 served as a reference point for development activities, undertaken exclusively from the pool of national resources, and served as the basis for the preparation of the Community Support Framework for Poland. Bearing in mind the short programming period 2004-2006 of an incomplete regional policy in relation to the European Union's perspective 2000-2006, the proposed implementation system - in particular in the scope of actions envisaged for implementation under the regional development program - was transitory and the experience gained by all participating entities in the implementation of cohesion policy contributed to its application in the subsequent periods of implementation of the EU cohesion policy (NDP 2003, p. 7).

The implementation of the 2004-2006 budget perspective was combined with the preparations for programming the new multi-annual budget period 2007-13. In the legal dimension, the Act of December 12, 2006 on principles of development and the Act of November 8, 2008 on amending certain acts in connection with the implementation of Structural Funds and the Cohesion Fund were adopted. Undertaking the work on the new programming period was also a pretext to reassess the socio-economic situation in the EU and its member states as well as political goals. During revision of development goals in Poland, a strategic document was adopted, which primarily constituted for the basis of the cohesion policy programming process in the next seven years, a document called the National Development Strategy 2007-2015. It set goals and priorities for the socio-economic development of Poland and the conditions that should ensure this development. The key areas included: increased competitiveness and innovativeness of the economy; improvement of the basic infrastructure condition; increase in employment and increase of its quality; building an integrated community, security system and rules of cooperation; regional development and increasing territorial cohesion (NDS 2007-2015, 2006, pp. 4-10).

In 2008, at the initiative of the Strategic Advisory Group at the Prime Minister, existing solutions at that time were reviewed and changes were recommended in the area of strategic management of Poland's development presented in the further part of the considerations. The justification for the changes was the need to have a new "compass of development", which, after the period of implementation of accession goals and short-term needs characteristic of 
societies in the transformation phase, prevented the so-called "development drift" situation, that is, stable growth, but too small to get closer to the most developed Western countries.

\section{Development management system in Poland - shortcomings and directions of changes}

While carrying out a diagnosis of the strategic development management system in Poland, it should be stated that in the strategic programming layer over the past years, it has begun to evolve and adapt to the needs arising, both, from internal and external conditions for the country's development. Although this process is not yet completed, it should be noted that it functions well in the part concerning programming of activities financed from the European Union budget. Attempts to transfer these experiences and solutions to other areas encounter resistance or reluctance before such changes. Unfortunately, deficits are still visible as far as the adopted scope and role of development policy and between socio-economic and territorial programming, which causes difficulties in setting strategic goals and their effective implementation. The separation of spatial planning from socio-economic planning for many years did not allow for, on the one hand, identification of adverse phenomena, and on the other hand, solving spatial conflicts at an early stage of their occurrence. The socio-economic and territorial planning separateness was also manifested in insufficient references to spatial and regional aspects in socio-economic strategic documents, while losing the function of spatial planning integration in relation to strategic planning. A substantial deficiency in terms of strategic programming was the lack of continuity resulting from the change of governmental teams and the related lack of perspective on development activities in the long-term perspective. The result of such a state of affairs was, among others, the existence of about 200 documents of a strategic nature at the national level - most often with a short- and medium-term perspective, while lacking a clearly defined longterm vision of the country's development, which in turn led to the dissolution of objectives, duplication of actions or supporting mutually abolishing ideas (Assumptions 2009, pp. 7-8).

Along with the analysis of the process of shaping the institutional system, which should ensure efficient cooperation of individual entities participating in the construction and implementation of development policy, it should be stated that it has not been fully grown. Unfortunately, in the structure of administration in Poland there was no separate central unit responsible 
for broadly understood, comprehensive development management, which would be responsible for coordination of work on all strategic documents, ensuring their effective implementation and assessment of the results of their implementation. This state of affairs caused insufficient coordination of operations both in the programming and implementation spheres. At the time, the sectoral approach was predominant, which was characterized by programming of actions in relation to a specific sector and the unwillingness to program actions which were out of the scope of responsibility of a given department, which still were important from the point of view of the country's development, all that resulted in a limited horizontal approach. In addition, it is pointed out that the political leadership of individual public administration units has often not been sufficiently involved in the strategic programming process. The management of these units did not always identify themselves with the program documents developed by their unit and did not feel personally responsible for their effective implementation. Often, political leadership was missing in the form of the host of the document, which would make it possible to assign more importance and significance to the prepared documents, and consequently their greater implementation. After the accession to the European Union, the center of gravity in strategic programming was moved to the Ministry of Regional Development, which favored the process of desirable changes presented in the earlier part of the considerations in this article. It should be added only that the then regional development ministry did not possess sufficiently effective instruments to enforce relevant standards in the field of strategic programming. Furthermore, it should be noted that also other centers were involved in the coordination of individual policies, thereby implementing accession commitments. The Ministry of Finance played this role in the field of macroeconomic and structural policy under the Convergence Program, while the Ministry of Economy in the implementation of the Lisbon Strategy in Poland implementing the National Reform Program. Unfortunately, there was no common basis for program actions undertaken by these centers, which would combine tasks carried out as part of the national development policy with program tasks resulting directly from EU commitments. Undoubtedly, one weakness of the current programming system and implementation of development policies in Poland was failure to employ cooperation between partners representing various public institutions, private entities or non-governmental organizations in order to ensure achievement of development goals, at the national, regional and local levels as well (Foundations 2009, p. 8-9). 
Implementation of development policy, which consists of monitoring implemented policies and the assessment of the degree of their implementation, has developed mainly in the framework of realization of actions financed from EU funds. In the remaining areas, monitoring and evaluation activities are limited and focus excessively on financial expenditures and implementation procedures, whereas it is completely disregarded or limited how they assess the effectiveness and the degree of implementation of these activities in the context of the overall development policy. One reservation also raises with the method of financing development policy because, as a tool of its implementation, this method does not guarantee effective realization of the undertaken actions. Budget planning was not sufficiently related to strategic objectives of development policy, which results in the funds being diffused, duplicated and allocated to activities and initiatives that are not consistent and well-thought-out. In this context, attention should be paid to one more weakness, namely the lack of long-term financial planning that would cover all public funds. Concluding and closing the critical analysis of the development management system, the basic shortcomings include (Assumptions 2009, pp. 10-11):

- weakness and inefficiency of the programming system, making it impossible to fully achieve development policy objectives,

- insufficient connection of the level of programming with the operational level,

- lack of a strong coordination center for development policy, as well as the lack of efficient channels of cooperation between its various entities,

- insufficient involvement of the political leadership of public administration units in program-strategic work,

- separation of spatial planning from socio-economic planning,

- insufficiently defined relations between development policy and regional policy,

- lack of transparent and long-term financing of development policy.

The diagnosis of the Polish development management system was used to determine the desired directions of change. At the same time one should emphasize that the effective functioning of the development management system depends to a large extent on the determination of its shape and the role it should play in implementing the country's development policy. In this context, it was stated that development policy should include nodal thematic areas, both those under the responsibility of individual ministries, as well as those that are sub-ministry areas. It is necessary, both among politicians and public administration, to change the way of thinking about development policy and looking at development activities in the long term, while focusing on issues 
of real weight for the country. Effective implementation of development policy is determined by the following necessary prerequisites (Assumptions 2009, pp. 12-21):

- clarification of the scope and role of development policy along with formulation of strategic objectives, including in particular ensuring integration of the socio-economic and territorial dimension, as one of the main principles of building a strategic programming system and ensuring consistency of all sectoral, domain and regional policies; defining the role and place of regional policy in the framework of development policy and modification of strategic objectives of regional policy in the context of new national, European and global challenges, commitment to the implementation of development policy objectives at all levels of public administration,

- development of a programming system ensuring the implementation of development policy objectives,

- ensuring an effective coordination center for development policy and securing efficient cooperation channels,

- creation of a uniform implementation system, including monitoring, evaluation, and introduction of uniform standards for strategic development management in public administration.

- creation of public finance system as an effective means of implementing the state development policy,

- ensuring appropriate instruments for implementation of development policy. As it has already been mentioned, in 2008, at the initiative of the Strategic Advisory Group at the Prime Minister, the solutions at that time were reviewed and recommendations were made regarding strategic management of Poland's development which are presented above. As a result, Poland has introduced a development management system which allows for efficient management of the state development policy. This policy allows defining development goals and planning their implementation. This allows us to plan the right path of development and we can also manage the available resources rationally. On 27 April 2009 the Council of Ministers adopted the document "Assumptions for the Development Management System of Poland" which along with further work resulted in the acceptance of the national development management system based on the Long-term Country Development Strategy - Poland 2030, the third wave of modernity, Medium-Term National Development Strategy, the package of 9 complementary integrated strategies, ie the Strategy for Innovation and Economic Efficiency, Human Capital Development Strategy, Energy Security and Environment Strategy, National Strategy of Regional Development, Transport 
Development Strategy, Sustainable Rural Development, Agriculture and Fishery Strategy, Efficient State Strategy, Social Capital Development Strategy and RP Security System Development Strategy.

The documents constituting the new strategic order also included the Concept of Spatial Development of the Country, building relations between space and social and economic development, and this is the most important government strategy regarding spatial development of the country (Poland 2030, 2013, p. 12). Apart from these documents, four supra-regional strategies have also appeared in the development management system. Such strategies are created for two or more voivodships, which involves not only geographical neighborhood but also other factors, e.g. common development goals and challenges, investment needs, similar natural conditions, history. It should be noted that work on supraregional strategies always takes place in consultation with local governments as well as social and economic partners. Currently, there are four supra-regional strategies, namely: Strategy for socio-economic development of Eastern Poland until 2020, Strategy for Development of Southern Poland until 2020, Strategy for Development of Western Poland until 2020, and Strategy for Development of Central Poland until 2020 with a 2030 perspective. To conclude it is necessary to emphasize that various entities are involved in the implementation of the government's development policy. The body coordinating their activities is the Coordination Committee for Development Policy, an advisory and consultative body of the Prime Minister, composed of representatives of ministries, and the work is chaired by the Minister of Development (http://www.mpit.gov.pl, date of access 30.01 .2017).

\section{Summary}

Poland has undergone the process of political transformation, as well as the process of integration with the European Union, as a result of which there have been changes that allowed the adoption of standards and solutions already existing in the Member States of the European Union. Naturally, the processes of transformation and European integration progressed with varying intensity in various areas of socio-economic life. Undoubtedly, one of the key areas that significantly influenced the formation of Poland was founding the development management system. Therefore, the undertaking of this problem was extremely important from the point of view of conscious and responsible creation of the future of Poland. Referring to the process of shaping the country's development management system, it should be noted that it has traveled a long and bumpy 
road, determined in the greatest extent by the aforementioned processes of political transformation, and above all European integration. Over time, Poland gained further experience, adopted specific legal regulations, changed the territorial organization of the country, the structure of central administration, and adopted a number of program solutions conducive to the development of a comprehensive development management system adapted to the current challenges. Today, from the perspective of previous experience, it can be stated that the task has been fine-tuned and Poland has shaped, not only the foundations, but also the development management system. Yes, there are still shortcomings, which should be consistently eliminated, but it can be said that not only the awareness has been developed in Poland, but there is an increasing maturity for conscious management of the country's development.

\section{Summary}

\section{Institutionalization of the development management system in} Poland

The Polish development policy was shaped along with the process of political transformation and integration with the European Union. After 1990, the management of development policy had a provisional character, in fact the system did not exist. At the national level, there was certain lack of the legal framework, strategic documents, institutional framework and financing. The progressively progressing process of European integration, the transfer of pre-accession funds and the prospect of EU membership and also the possibility of implementing cohesion policy have enabled the adoption of solutions appropriate for many EU Member States. In the first phase, in 1998, exactly on 5 June, the law on voivodship and poviat level self-government was adopted. The following year, the act on departments was adopted, on the basis of which the office of the minister competent for development was established, and in 2000 the fundamental act of law was adopted, namely the act on the principles of supporting regional development. Along with the possibility of cohesion policy implementation, a strategic planning system was adopted, primarily for the purpose of taking advantage of the European funds, and the corresponding institutional set-up was created. However, it was only in 2008, at the initiative of the Strategic Advisory Group at the Prime Minister, that the solutions 
at that time were reviewed and changes were recommended in the area of strategic management of Poland's development. The justification for the changes was the need to have a new "compass of development", which after the period of implementation of accession goals and short-term needs characteristic of societies in the transformation phase prevented the so-called "development drift" situation, that is, stable growth, but too weak to compare to the most developed Western countries. After the adoption of the document "Assumptions of the development management system of Poland" by the Council of Ministers on 27 April 2009 and as a result of further work, a national development management system was developed.

Key words: development, system, management, development management system, public policy.

\section{Streszczenie}

\section{Instytucjonalizacja systemu zarządzania rozwojem w Polsce}

Polska polityka rozwoju kształtował się wraz z procesem transformacji ustrojowej oraz integracji z Unią Europejską. Po roku 1990 zarządzanie polityką rozwoju miało prowizoryczny charakter, de facto system nie istniał. Na poziomie ogólnokrajowym brakowało zarówno ram prawnych, dokumentów strategicznych, ram instytucjonalnych i sposobu finansowania. Sukcesywnie postępujący proces integracji europejskiej, transfer środków przedakcesyjnych oraz perspektywa członkostwa w UE i możliwość realizacji polityki spójności pozwoliły na przyjęcie rozwiązań właściwych dla wielu państw członkowskich UE. W pierwszej fazie, $\mathrm{w}$ roku 1998, dokładnie 5 czerwca przyjęto ustawy o samorządzie szczebla wojewódzkiego i powiatowego. $\mathrm{W}$ następnym roku uchwalono ustawę o działach, na podstawie której powołano urząd ministra właściwego do spraw rozwoju, a $\mathrm{w}$ roku 2000 przyjęto fundamentalny akt prawa, a mianowicie ustawę o zasadach wspierania rozwoju regionalnego. Wraz z możliwością realizacji polityki spójności przyjęto system planowania strategicznego, przede wszystkim na potrzeby wydatkowania środków europejskich oraz stworzono układ instytucjonalny. Jednak dopiero $\mathrm{w}$ roku $2008 \mathrm{z}$ inicjatywy 
Zespołu Doradców Strategicznych przy Prezesie Rady Ministrów dokonano przeglądu ówczesnych rozwiązań i zarekomendowano zmiany $\mathrm{w}$ obszarze strategicznego zarządzania rozwojem Polski. Uzasadnieniem dla zmian była potrzeba posiadania nowego „kompasu rozwojowego”, który po okresie realizacji celów akcesyjnych i doraźnych potrzeb charakterystycznych dla społeczeństw $\mathrm{w}$ fazie transformacji zapobiegły sytuacji tzw. „,dryfu rozwojowego", to znaczy wzrostu stabilnego, lecz zbyt małego aby zbliżyć się do najbardziej rozwiniętych państw Zachodu. Po przyjęciu 27 kwietnia 2009 roku przez Radę Ministrów dokumentu "Założenia systemu zarządzania rozwojem Polski" oraz w wyniku dalszych prac opracowano system zarządzania rozwojem kraju.

Kluczowe słowa:

rozwój, system, zarządzanie, system zarządzania rozwojem, polityka publiczna.

JEL

Classification: D72 D73 D74 D78 H70 H79 H83 O18 P1

\section{References}

1. Adamowicz M. (2011), Wsparcie rozwoju regionalnego w warunkach uczestnictwa Polski w Unii Europejskiej, „Roczniki Nauk Rolniczych”, Seria G, Vol. 98, iss. 1.

2. Churski P. (2008), Czynniki rozwoju regionalnego i polityka regionalna w Polsce w okresie integracji z Unia Europejska, UAM Poznań.

3. Gilowska Z., Hausner J., Fraczek M., Sułkowski R., Lodkowska-Skoneczka G., Miller J., Pyszkowski A., Sartorius W., Szlachta, J., Zalewski J., Dżedzyk J., Żuber P. (2001), Koncepcja polityki rozwoju regionalnego w perspektywie akcesji Polski do Unii Europejskiej, Warszawa.

4. Górniaka J., Mazura S. (eds.), (2012), Zarządzanie strategiczne rozwojem, Ministerstwo Rozwoju Regionalnego, Warszawa 2012.

5. Hausner J. (2008), Zarzadzanie publiczne, Wydawnictwo Naukowe Scholar, Warszawa.

6. Kundera J., Szmyt W. (2008), Leksykon polityki regionalnej Unii Europejskiej, Wolters Kluwer, Polska, Kraków.

7. Legutko-Kobus P. (2015), Partycypacja w kreowaniu polityk publicznych [w:] Strzelecki Z. (red.), Wybrane regionalne i lokalne polityki publiczne w Polsce. 10 lat doświadczeń w warunkach członkostwa w Unii Europejskiej, Ministerstwo Infrastruktury i Rozwoju, Warszawa. 
8. Sługocki W. (2014), Od podejścia scentralizowanego do zintegrowanego - próba określenia kierunków ewolucji polityki spójności UE realizowanej w Polsce w latach 2004-2020 [in:] Jakubowski E., Sługocki W. (eds.), Polska w Unii Europejskiej. Gospodarka. Energetyka. Region, Dom Wydawniczy Elipsa, Warszawa.

9. Sługocki W., (2013), Polityka regionalna Unii Europejskiej a rozwój polskich regionów - studium przypadku, Oficyna Wydawnicza UZ, Zielona Góra.

10. Sługocki W. (2005), Wybrane aspekty finansowego wsparcia Unii Europejskiej $w$ Polsce, Uniwersytet Zielonogórski, Zielona Góra.

11. Szlachta J., Zalewski J. (2010), Kierunki polityki regionalnej w Polsce do roku 2020, "Gospodarka Narodowa”, No. 10, pp. 37-38.

12. Zwierżdżyński M. K. (2015), Strategie rozwoju Polski: analiza systemu, wyzwania i rekomendacje, "Horyzont Polityki”, Vol. 6, No. 16, pp. 14-15.

13. Krajowa Strategia Rozwoju Regionalnego 2010-2020: Regiony, miasta, obszary wiejskie, (2010), Warszawa.

14. Narodowy Plan Rozwoju, (2003),Rada Ministrów RP, Warszawa.

15. Polska 2030. Trzecia fala nowoczesności. Dtugookresowa Strategia Rozwoju Kraju, (2013) ,Ministerstwo Administracji i Cyfryzacji, Warszawa.

16. Raport o rozwoju i polityce regionalnej, (2007), Ministerstwo Rozwoju Regionalnego, Warszawa.

17. Strategia Rozwoju Kraju 2007-2015, (2006), Ministerstwo Rozwoju Regionalnego, Warszawa.

18. Założenia systemu zarządzania rozwojem w Polsce, (2009), Ministerstwo Rozwoju Regionalnego, Warszawa.

19. Ustawa $\mathrm{z}$ dnia 6 grudnia 2006 roku o zasadach prowadzenia polityki rozwoju (Dz. U. nr 227/2006 poz. 1658).

20. http://www.mpit.gov.pl/strony/zadania/polityka-rozwoju-kraju/ zarzadzanie-rozwojem-kraju / czym-jest-zarzadzanie-rozwojem/ (30.01.2018 - access date). 